\title{
Origin of nondetectable x-ray diffraction peaks in nanocomposite CuTiZr alloys
}

\author{
Jiang, Jianzhong; Kato, H.; Ohsuna, T.; Saida, J.; Inoue, A.; Saksl, K.; Franz, H.; Ståhl, Kenny
}

Published in:

Applied Physics Letters

Link to article, DOI:

$10.1063 / 1.1619220$

Publication date:

2003

Document Version

Publisher's PDF, also known as Version of record

Link back to DTU Orbit

Citation (APA):

Jiang, J., Kato, H., Ohsuna, T., Saida, J., Inoue, A., Saksl, K., Franz, H., \& Ståhl, K. (2003). Origin of nondetectable x-ray diffraction peaks in nanocomposite CuTiZr alloys. Applied Physics Letters, 83(16), 32993301. https://doi.org/10.1063/1.1619220

\section{General rights}

Copyright and moral rights for the publications made accessible in the public portal are retained by the authors and/or other copyright owners and it is a condition of accessing publications that users recognise and abide by the legal requirements associated with these rights.

- Users may download and print one copy of any publication from the public portal for the purpose of private study or research.

- You may not further distribute the material or use it for any profit-making activity or commercial gain

- You may freely distribute the URL identifying the publication in the public portal 


\title{
Origin of nondetectable $x$-ray diffraction peaks in nanocomposite CuTiZr alloys
}

\author{
J. Z. Jiang ${ }^{\text {a) }}$ \\ Department of Physics, Building 307, Technical University of Denmark, DK-2800 Lyngby, Denmark \\ and Department of Materials Science and Engineering, Zhejiang University, Hangzhou, 310027, \\ People's Republic of China \\ H. Kato, T. Ohsuna, J. Saida, and A. Inoue \\ Institute for Materials Research, Tohoku University, Sendai 980-8577, Japan \\ K. Saksl and H. Franz \\ HASYLAB am DESY, Notkestrasse 85, D-22603 Hamburg, Germany \\ K. Ståhl \\ Department of Chemistry, Building 207, Technical University of Denmark, DK-2800 Lyngby, Denmark
}

(Received 19 May 2003; accepted 20 August 2003)

\begin{abstract}
Microscopic structures of $\mathrm{Cu}_{60} \mathrm{Ti}_{10+x} \mathrm{Zr}_{30-x}$ ( $x=0$ and 10) alloys have been investigated by transmission electron microscopy, $\mathrm{x}$-ray diffraction (XRD) and differential scanning calorimeter (DSC). In the $\mathrm{Cu}_{60} \mathrm{Ti}_{10} \mathrm{Zr}_{30}$ samples annealed at $708 \mathrm{~K}$ for times ranging from 0 to $130 \mathrm{~min}$, where the enthalpy of the first exothermic peak decreases by $80 \%$, the corresponding XRD patterns still look similar to that for the as-prepared sample. However, the simulated XRD patterns for the pure $\mathrm{Cu}_{51} \mathrm{Zr}_{14}$ phase, which is the crystalline phase formed during the first exothermic reaction, with small grain sizes and defects clearly show a broadened amorphous-like feature. This might be the reason that no diffraction peaks from the nanocrystalline component were detected in the XRD patterns recorded for the as-cast or as-spun $\mathrm{Cu}_{60} \mathrm{Ti}_{10+x} \mathrm{Zr}_{30-x}$ ( $x=0$ and 10) alloys and for the alloys annealed at lower temperatures, in which the enthalpy of the first exothermic peak has a significant reduction. The second exothermic peak found in DSC curves is due to the formation of another hexagonal phase, spacing group $P 6_{3} / m m c$ (194) and lattice parameters $a=5.105 \AA$ and $c=8.231$ A. (C) 2003 American Institute of Physics. [DOI: 10.1063/1.1619220]
\end{abstract}

In 1995, the $\mathrm{Cu}-\mathrm{Ti}-\mathrm{Zr}-\mathrm{Ni}$ system, the first $\mathrm{Cu}$-rich bulk metallic glass forming alloys, ${ }^{1}$ was discovered and then $\mathrm{Cu}-$ $\mathrm{Ti}-\mathrm{Zr}-\mathrm{Ni}-\mathrm{Si}$ and $\mathrm{Cu}-\mathrm{Ti}-\mathrm{Zr}-\mathrm{Ni}-\mathrm{Sn}$ systems were reported. ${ }^{2-4}$ Very recently, the report of ternary $\mathrm{Cu}_{60} \mathrm{Ti}_{10} \mathrm{Zr}_{30}$ and $\mathrm{Cu}_{60} \mathrm{Ti}_{15} \mathrm{Hf}_{25}$ systems, ${ }^{5,6}$ exhibiting excellent mechanical properties, has triggered considerable research activity in this area, ${ }^{5-26}$ especially in the microstructure of the ternary systems. ${ }^{5-12}$ Inoue et al.,${ }^{5,6}$ reported that bulk glassy alloys with a rod diameter of $4 \mathrm{~mm}$ can be formed in the ternary $\mathrm{Cu}_{60} \mathrm{Ti}_{10} \mathrm{Zr}_{30}$ and $\mathrm{Cu}_{60} \mathrm{Ti}_{15} \mathrm{Hf}_{25}$ systems. However, only the $\mathrm{x}$-ray diffraction (XRD) technique was applied to characterize the samples. Louzguine and Inoue ${ }^{7,8}$ further studied the microstructures of the samples annealed at various stages using transmission electron microscopy (TEM). Formation of nanocrystals in annealed samples was observed. Electron microscopic $^{\text {studies }}{ }^{9-11}$ on both as-cast and as-spun $\mathrm{Cu}_{60} \mathrm{Ti}_{10} \mathrm{Zr}_{30}$ samples clearly demonstrated that as-prepared samples contain significant volume fraction (about 5\%$10 \%$ ) of nanocrystals with diameters ranging from 5 to 15 $\mathrm{nm}$. It is concluded that the as-prepared ternary samples are classified as a nanocomposite: nanocrystals embedded in an amorphous matrix. However, one experimental fact reported in the literature $e^{5-12}$ still remains a puzzle for the community, i.e., no diffraction peaks from the nanocrystalline component

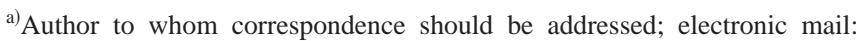
jiang@fysik.dtu.dk
}

were detected in the XRD patterns recorded for the as-cast or as-spun $\mathrm{Cu}_{60} \mathrm{Ti}_{10} \mathrm{Zr}_{30}$ samples. In this letter, we uncover the origin of the puzzle by performing TEM, XRD and differential scanning calorimeter (DSC) measurements of asprepared and annealed $\mathrm{Cu}_{60} \mathrm{Ti}_{10} \mathrm{Zr}_{30}$ and $\mathrm{Cu}_{60} \mathrm{Ti}_{20} \mathrm{Zr}_{20}$ alloys.

Alloy ingots with the composition of $\mathrm{Cu}_{60} \mathrm{Ti}_{10} \mathrm{Zr}_{30}$ and $\mathrm{Cu}_{60} \mathrm{Ti}_{20} \mathrm{Zr}_{20}$ were prepared by arc melting pure metals of 99.99\% copper, $99.9 \%$ zirconium, and $99.9 \%$ titanium in a purified argon atmosphere. Cylindrical $\mathrm{Cu}_{60} \mathrm{Ti}_{10} \mathrm{Zr}_{30}$ and $\mathrm{Cu}_{60} \mathrm{Ti}_{20} \mathrm{Zr}_{20}$ samples of $2.5 \mathrm{~mm}$ in diameter were prepared by a copper mold casting method. Ribbons of $\mathrm{Cu}_{60} \mathrm{Ti}_{10} \mathrm{Zr}_{30}$ and $\mathrm{Cu}_{60} \mathrm{Ti}_{20} \mathrm{Zr}_{20}$ samples were prepared by the meltspinning method. Heating treatments of the as-cast rod was carried out in a vacuum of $10^{-5}$ mbar at $708 \mathrm{~K}$ for various times from 0 to $42.3 \mathrm{ks}$. Room-temperature XRD measurements were carried out with $\mathrm{Cu} K_{\alpha}$ radiation and in situ hightemperature XRD measurements were carried out at beamline Petra1, HASYLAB in Hamburg, Germany, using a wavelength of $0.3542 \AA$ and an image plate detector. Samples in capillary tubes with a vacuum of $10^{-5}$ mbar were heated with a heating rate of $3 \mathrm{~K} / \mathrm{min}$. Thermal analyses were performed in a Seiko DSC6300 DSC at a heating rate of $0.33 \mathrm{~K} / \mathrm{s}$ under a flow of purified argon. Both $\mathrm{Cu}_{60} \mathrm{Ti}_{10} \mathrm{Zr}_{30}$ and $\mathrm{Cu}_{60} \mathrm{Ti}_{20} \mathrm{Zr}_{20}$ ribbon samples show a similar thermal behavior. The microstructures of the alloy were examined by using field-emission gun high-resolution transmission electron microscopy with an accelerating voltage of $300 \mathrm{kV}$ 

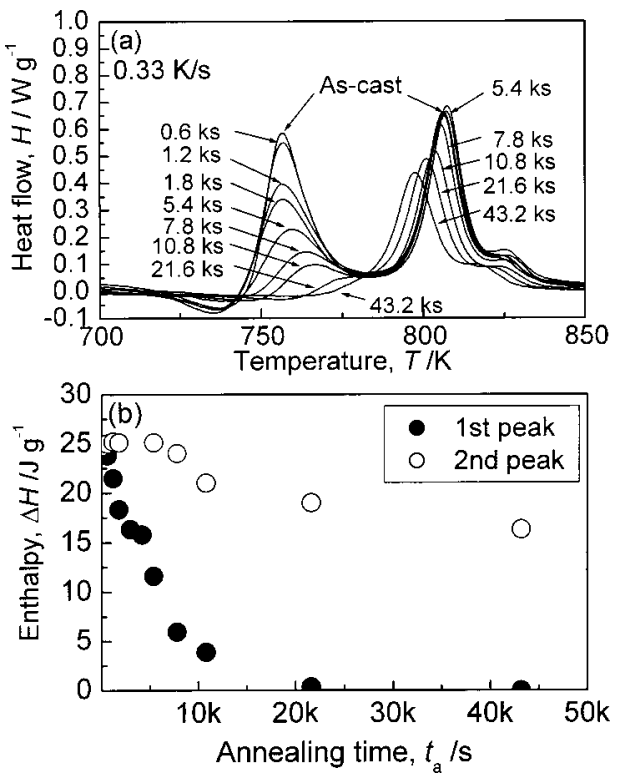

FIG. 1. DSC curves (a) and the time dependence of the first and second exothermic peak areas (b) for the as-cast $\mathrm{Cu}_{60} \mathrm{Ti}_{10} \mathrm{Zr}_{30}$ rod and samples annealed at $708 \mathrm{~K}$ for various times.

(JEOL JEM-3000F). TEM specimens were prepared by lowenergy ion milling at $2.5 \mathrm{kV}$ and $5 \mathrm{~mA}$ with liquid nitrogen cooling.

Figure 1 shows DSC curves and the time dependence of the first and second exothermic peak areas for the as-cast and annealed $\mathrm{Cu}_{60} \mathrm{Ti}_{10} \mathrm{Zr}_{30}$ rods. The DSC curve for the as-cast rod is in good agreement with data reported in the literature. ${ }^{5-12}$ With increasing annealing time, the enthalpy of the first exothermic peak monotonically decreases from 25 $\mathrm{J} / \mathrm{g}$ for the as-cast rod to about $5 \mathrm{~J} / \mathrm{g}$ for the sample annealed for $7.8 \mathrm{ks}$, while the second exothermic peak remains almost unchanged within experimental uncertainty. With further increasing annealing time, the second exothermic peak starts to decrease and its position shifts to low temperatures. For 42.3 ks, the first exothermic peak disappears and the enthalpy of the second exothermic peak has a 35\% reduction. Figure 2 shows TEM dark-field images of the as-cast $\mathrm{Cu}_{60} \mathrm{Ti}_{10} \mathrm{Zr}_{30}$ rod and the sample annealed at $708 \mathrm{~K}$ for $7.8 \mathrm{ks}$. The nanocomposite microstructure for the as-cast rod is seen to consist of nanocrystals ranging 7-15 $\mathrm{nm}$ embedded in an amorphous matrix, which is consistent with the data reported in Refs. 9-11. Two striking features were detected from the image for the annealed sample: (1) the sample is dominated by nanocrystals and (2) the average size of nanocrystals of about $5 \mathrm{~nm}$ is smaller than that for the as-cast rod. The results strongly suggest that the first exothermic peak in Fig. 1 may be due to the primary nanocrystallization of the amorphous matrix of the as-cast sample. Figure 3 shows XRD patterns of as-cast $\mathrm{Cu}_{60} \mathrm{Ti}_{10} \mathrm{Zr}_{30}$ rod and samples annealed at $708 \mathrm{~K}$ for various times. It is surprisingly found that samples annealed at $708 \mathrm{~K}$ for a time less than $8 \mathrm{ks}$ have a similar XRD pattern with the as-cast rod although the enthalpy of the first exothermic peak drops by $80 \%$ as compared to the as-cast rod in Fig. 1. No crystalline diffraction peaks were detected in the sample annealed at $708 \mathrm{~K}$ for $7.8 \mathrm{ks}$. By fitting the broad peak located at $2 \theta \approx 40^{\circ}$ using both Lorentz and Gauss line profiles, it is clear that the width at the half Downloaded 01 Apr 2010 to 192.38.67.112. Redistribution subject

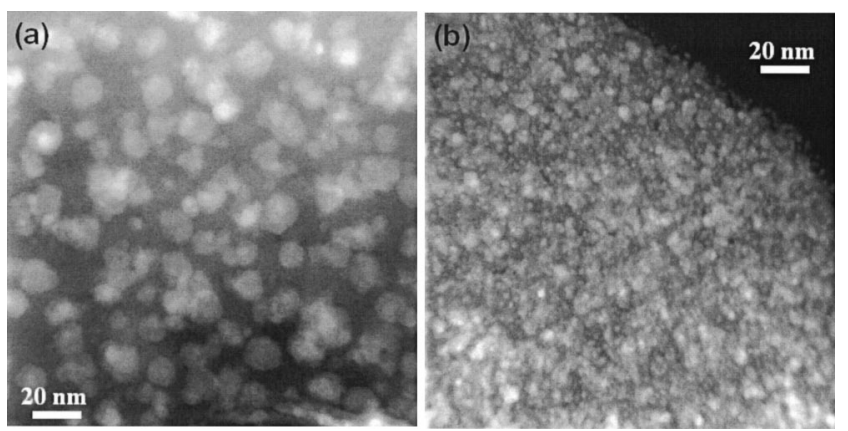

FIG. 2. TEM dark-field images for the as-cast $\mathrm{Cu}_{60} \mathrm{Ti}_{10} \mathrm{Zr}_{30}$ rod (a) and the sample annealed at $708 \mathrm{~K}$ for $130 \mathrm{~min}$ in a vacuum of $1 \times 10^{-5}$ mbar (b).

maximum (FWHM) in Fig. 3(b)(ii) decreases by a factor about $16 \%$ from as-cast to the sample annealed for $7.8 \mathrm{ks}$. The XRD pattern [Fig. 3(c)] recorded for the sample annealed for $42.3 \mathrm{ks}$ shows diffraction peaks, which can be indexed to a hexagonal phase (hereafter marked H2), space group $P 6_{3} / m m c(194)$ and lattice parameters $a=5.105 \AA$ and $c=8.231 \AA$. We believe that this crystalline phase corresponds to the reduction of the second exothermic peak in Fig. 1. In situ high temperature XRD measurements for both $\mathrm{Cu}_{60} \mathrm{Ti}_{10} \mathrm{Zr}_{30}$ and $\mathrm{Cu}_{60} \mathrm{Ti}_{20} \mathrm{Zr}_{20}$ ribbons were performed. Both alloys have similar DSC curves, indicating a similar crystallization process. ${ }^{11,12}$ It found that the first detectable diffraction peaks for the $\mathrm{Cu}_{60} \mathrm{Ti}_{10} \mathrm{Zr}_{30}$ glass are from the $\mathrm{H} 2$ phase. However, for the $\mathrm{Cu}_{60} \mathrm{Ti}_{20} \mathrm{Zr}_{20}$ glass, the first detectable diffraction peaks are not from the $\mathrm{H} 2$ phase, as shown in Fig. 4. The peak recorded at $741 \mathrm{~K}$ looks very broad, similar to an amorphous-like pattern, but slight narrower than the pattern recorded at $295 \mathrm{~K}$. The intensity at $2 \theta \approx 10^{\circ}$ is higher than the pattern recorded at $295 \mathrm{~K}$. Diffraction peaks, superimposed on the broadened amorphous peak, appear at $756 \mathrm{~K}$, which can be indexed as a new hexagonal phase (hereafter marked H1), space group $P 6 / m(175)$ and lattice parameters $a=11.235 \AA$ and $c=8.271 \AA$. This phase is similar to a $\mathrm{Cu}_{51} \mathrm{Zr}_{14}$ phase. At temperatures above $790 \mathrm{~K}$, the $\mathrm{H} 2$ phase appears. We further simulated the XRD patterns for the pure $\mathrm{H} 1$ phase with various grain sizes as shown in Fig. 4(b), in which we did not take into account defects and strain effects. For small grain sizes, diffraction peaks for the $\mathrm{H} 1$ phase strongly overlap. Consequently, the simulated patterns for grains less than $5 \mathrm{~nm}$ look indeed similar to an amorphouslike pattern as the pattern recorded at $741 \mathrm{~K}$ in Fig. 4(a). The peak width at around $2 \theta \approx 8.8^{\circ}$ does get narrower as shown in Fig. 3(b) and the intensity at $2 \theta \approx 10^{\circ}$ does increase as observed in Fig. 4(a). Note that defects, e.g., nonstoichiometric composition, interfaces, and microstrain, which most likely exist in the nanocomposite alloys, could further broaden diffraction peaks. Therefore, although the TEM results in Fig. 2 reveal that the average grain size of nanocrystals in the $\mathrm{Cu}_{60} \mathrm{Ti}_{10} \mathrm{Zr}_{30}$ rod sample annealed at $708 \mathrm{~K}$ for $7.8 \mathrm{ks}$ is about $5 \mathrm{~nm}$, diffraction peaks from the $\mathrm{H} 1$ phase could still not be visible, as experimentally observed in Fig. 3. It also found that the average crystal size of the $\mathrm{H} 1$ phase in the $\mathrm{Cu}_{60} \mathrm{Ti}_{20} \mathrm{Zr}_{20}$ alloy is larger than that in the $\mathrm{Cu}_{60} \mathrm{Ti}_{10} \mathrm{Zr}_{30}$ alloy, which results in the appearance of diffraction peaks from the $\mathrm{H} 1$ phase prior to the $\mathrm{H} 2$ phase in the XRD patterns in the $\mathrm{Cu}_{60} \mathrm{Ti}_{20} \mathrm{Zr}_{20}$ alloy. In addition, Xing et al. ${ }^{27}$ AIP license or copyright; see http://apl.aip.org/apl/copyright.jsp 

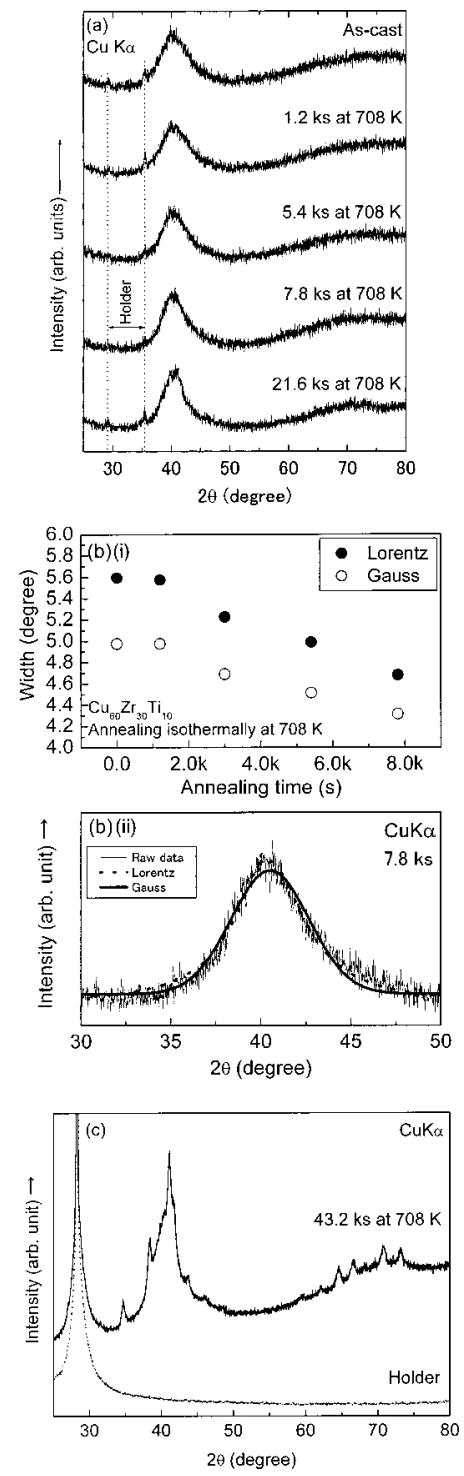

FIG. 3. (a) XRD patterns recorded for the as-cast $\mathrm{Cu}_{60} \mathrm{Ti}_{10} \mathrm{Zr}_{30}$ rod and samples annealed at $708 \mathrm{~K}$ for various times. The XRD pattern for sample holder $\mathrm{Al}$ is also included. (b) Fitting profiles of the peak located at $2 \theta \approx 40^{\circ}$ using both Lorentz and Gauss line profiles (i) and the width at the half maximum as a function of annealing time (ii). (c) The XRD pattern recorded for the $\mathrm{Cu}_{60} \mathrm{Ti}_{10} \mathrm{Zr}_{30}$ rod annealed at $708 \mathrm{~K}$ for $12 \mathrm{~h}$. The XRD pattern for the sample holder $\mathrm{Si}$ is also included.

observed a similar phenomenon in a nanostructured $\mathrm{Zr}_{54.5} \mathrm{Ti}_{7.5} \mathrm{Cu}_{20} \mathrm{Ni}_{8} \mathrm{Al}_{10}$ alloy, in which they also suggested the particle size effect for the nondetectable x-ray diffraction peaks for quasicrystals.

In conclusion, microscopic structures of $\mathrm{Cu}_{60} \mathrm{Ti}_{10+x} \mathrm{Zr}_{30-x}(x=0$ and 10$)$ alloys have been investigated by TEM, XRD, and DSC. The first crystalline phase formed during constant rate heating is a $\mathrm{Cu}_{51} \mathrm{Zr}_{14}$-like phase [spacing group $P 6 / m$ (175) and lattice parameters $a=11.235$ $\AA$ and $c=8.271 \AA]$ with nanometer-sized grains. The first exothermic peak found in DSC curves corresponds to the amorphous-to-nanocrystalline $\mathrm{Cu}_{51} \mathrm{Zr}_{14}$-like phase transition. Due to overlapping of the diffraction peaks, XRD is unable to distinguish a single amorphous phase from the nanocomposite of $\mathrm{Cu}_{51} \mathrm{Zr}_{14}$-like nanocrystals (with small grain sizes and defects) embedded in an amorphous matrix. The second
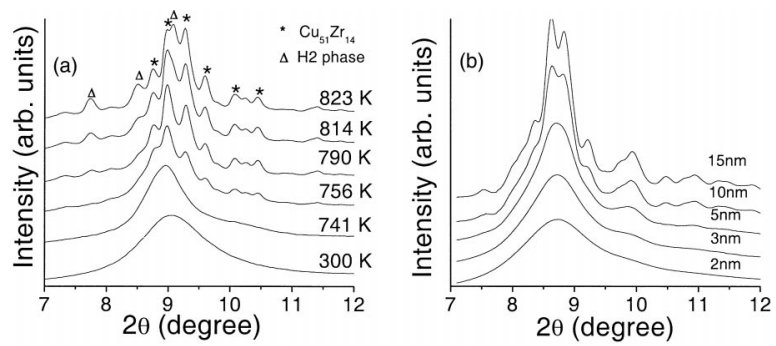

FIG. 4. (a) In situ high temperature XRD patterns for the $\mathrm{Cu}_{60} \mathrm{Ti}_{20} \mathrm{Zr}_{20}$ ribbon sample. (b) Simulated XRD patterns for the pure $\mathrm{Cu}_{51} \mathrm{Zr}_{14}$ phase with various grain sizes. Patterns were calculated using Voigt profile functions with constant Gaussian FWHM $=\operatorname{sqrt}\left[0.03-0.4 \tan (\theta)+0.3 \tan ^{2}(\theta)\right]$ degrees to simulate the instrumental peak broadening.

crystalline phase is also a hexagonal phase, space group $P 6_{3} / m m c$ (194) and lattice parameters $a=5.105 \AA$ and $c=8.231 \AA$, which occurs at the second exothermic peak found in DSC curves. The puzzle in the CuZrTi system, i.e., that no diffraction peaks from the nanocrystalline component were detected in the XRD patterns recorded for the as-cast or as-spun $\mathrm{Cu}_{60} \mathrm{Ti}_{10+x} \mathrm{Zr}_{30-x}(x=0$ and 10) alloys and for the alloys annealed at lower temperatures, in which the enthalpy of the first exothermic peak has a significant reduction, has been solved.

${ }^{1}$ X. H. Lin and W. L. Johnson, J. Appl. Phys. 78, 6514 (1995).

${ }^{2}$ H. Choi-Yim, R. Busch, and W. L. Johnson, J. Appl. Phys. 83, 7993 (1998).

${ }^{3}$ T. Zhang and A. Inoue, Mater. Trans., JIM 40, 301 (1999).

${ }^{4}$ C. Li, J. Saida, M. Kiminami, and A. Inoue, J. Non-Cryst. Solids 261, 108 (2000).

${ }^{5}$ A. Inoue, W. Zhang, T. Zhang, and K. Kurosaka, Mater. Trans., JIM 42, 1149 (2001).

${ }^{6}$ A. Inoue, W. Zhang, T. Zhang, and K. Kurosaka, Acta Mater. 49, 2645 (2001).

${ }^{7}$ D. V. Louzguine and A. Inoue, J. Mater. Res. 17, 2112 (2002).

${ }^{8}$ D. V. Louzguine and A. Inoue, Appl. Phys. Lett. 81, 2561 (2002).

${ }^{9}$ M. Kasai, J. Saida, M. Matsushita, T. Ohsuna, E. Matsubara, and A. Inoue, J. Phys.: Condens. Matter 14, 13867 (2002).

${ }^{10}$ Y. T. Chen, T. Zhang, W. Zhang, D. H. Ping, K. Hono, A. Inoue, and T. Sakurai, Mater. Trans., JIM 43, 2647 (2002).

${ }^{11}$ J. Z. Jiang, J. Saida, H. Kato, T. Ohsuna, and A. Inoue, Appl. Phys. Lett. 82, 4041 (2003).

${ }^{12}$ J. Z. Jiang, B. Yang, K. Saksl, H. Franz, and N. Pryds, J. Mater. Res. 18, 895 (2003).

${ }^{13}$ A. Inoue, W. Zhang, T. Zhang, and K. Kurosaka, J. Non-Cryst. Solids 304, 200 (2002).

${ }^{14}$ M. Calin, J. Eckert, and L. Schultz, Scr. Mater. 48, 653 (2002).

${ }^{15}$ W. Zhang, S. Ishihara, and A. Inoue, Mater. Trans., JIM 43, 1767 (2002).

${ }^{16}$ T. Zhang, T. Yamamoto, and A. Inoue, Mater. Trans., JIM 43, 3222 (2002).

${ }^{17}$ T. Zhang and A. Inoue, Mater. Trans., JIM 43, 1367 (2002).

${ }^{18}$ D. J. Sordelet, E. Rozhkova, P. Huang, P. B. Wheelock, M. F. Besser, M. J. Kramer, M. Clavo-Dahlborg, and U. Dahlborg, J. Mater. Res. 17, 186 (2002).

${ }^{19}$ E. S. Park, H. K. Lim, W. T. Kim, and D. H. Kim, J. Non-Cryst. Solids 298, 15 (2002).

${ }^{20}$ D. H. Bae, H. K. Lim, S. H. Kim, D. H. Kim, and W. T. Kim, Acta Mater. 50, 1749 (2002).

${ }^{21}$ D. J. Sordelet, E. Rozhkova, M. F. Besser, and M. J. Kramer, J. Non-Cryst. Solids 317, 137 (2003).

${ }^{22}$ T. Shindo, Y. Waseda, and A. Inoue, Mater. Trans., JIM 44, 351 (2003).

${ }^{23}$ D. V. Louzguine and A. Inoue, Philos. Mag. Lett. 83, 191 (2003).

${ }^{24}$ D. V. Louzguine and A. Inoue, Scr. Mater. 48, 1325 (2003).

${ }^{25}$ Q. S. Zhang, H. F. Zhang, Y. F. Deng, B. Z. Ding, and Z. Q. Hu, Scr. Mater. 49, 273 (2003)

${ }^{26}$ A. Inoue and W. Zhang, J. Mater. Res. 18, 1435 (2003).

${ }^{27}$ L. Q. Xing, T. C. Hufnagel, J. Eckert, W. Loser, and L. Schultz, Appl. Phys. Lett. 77, 1970 (2000). 